\title{
PENGARUH MODEL DISCOVERY LEARNING BERBASIS CONCEPT MAPPING TERHADAP HASIL BELAJAR KOGNITIF
}

\author{
Nunuy Nurawaliah', Adun Rusyana², Taupik Sopyan ${ }^{3}$ \\ 1,2,3Program Studi Pendidikan Biologi, Universitas Galuh, J.L. R. E. Martadinata No.150, Ciamis, Indonesia \\ Email: adunrusyana@gmail.com
}

\begin{abstract}
Cognitive is one of the domains of learning outcomes which is influenced by the learning process. Based on condition in the field, it is indicated that students only receives the material provided by the teacher; they have a lack of participation and low curiosity, as well as difficulty in remembering and understanding the material being studied. For this reason, innovation in learning is needed. This study aims to determine the effect of based-concept mapping discovery learning model towards students' cognitive learning outcomes on sub material of environmental pollution. The research using quasi-experimental method with the design of One Group Pretest Postest involves the population from all of students in Class X IPA MAN 2 Ciamis in the academic year 2019/2020. The selected sample is class X IPA 5 consisting of 27 students. The instrument test used in this study is in the form of multiple choice with the total number of 20 questions. Data obtained from the test is processed statistically. The results show that Z- count $3.125 \geq Z$ Z-table 2.33. It can be concluded that the use of a concept mapping based discovery learning model has a very significant effect on students' cognitive learning outcomes on environmental pollution sub material with a high level of increase by 0.80 .
\end{abstract}

Keywords: Discovery Learning, Concept Mapping, Cognitive Learning Outcomes.

\begin{abstract}
ABSTRAK
Kognitif merupakan salah satu ranah hasil belajar yang dipengaruhi oleh proses pembelajaran. Berdasarkan kondisi di lapangan, siswa cenderung terbiasa hanya menerima materi yang diberikan guru, kurang berpartisipasi, rendahnya rasa keingintahuan siswa, serta sulit mengingat dan memahami materi yang dipelajari. Oleh karena itu, diperlukan inovasi dalam pembelajaran sangat diperlukan. Penelitian ini bertujuan untuk mengetahui pengaruh model discovery learning berbasis concept mapping terhadap hasil belajar kognitif siswa pada sub materi pencemaran lingkungan. Penelitian ini menggunakan metode eksperimen semu (Quasi-Experiment) menggunakan desain One Group Pretest Postest. Populasi penelitian adalah seluruh siswa-siswi kelas X IPA MAN 2 Ciamis tahun ajaran 2019/2020 dengan melibatkan 27 siswa kelas X IPA 5 sebagai sampel. Instrumen test yang digunakan adalah soal pilihan ganda sebanyak 20 soal. Data yang diperoleh dari hasil test diolah secara statistik. Hasil penelitian menunjukan bahwa Z-hitung 3,125 Z Z-tabel 2,33. Disimpulkan bahwa penggunaan model discovery learning berbasis concept mapping berpengaruh sangat signifikan terhadap hasil belajar kognitif siswa pada sub materi pencemaran lingkungan dengan tingkat peningkatan tinggi yaitu sebesar 0,80 .
\end{abstract}

Kata Kunci: Discovery Learning, Concept Mapping , Hasil Belajar Kognitif.

Cara sitasi: Nurawaliah, N., Rusyana, A \& Sopyan, T. 2021. Pengaruh model discovery learning berbasis concept mapping terhadap hasil belajar kognitif. J-KIP (Jurnal Keguruan dan IImu Pendidikan), 2 (2), 33-38. 


\section{PENDAHULUAN}

Pembelajaran merupakan suatu interaksi antara peserta didik, guru dan sumber belajar pada suatu lingkungan belajar untuk memperoleh ilmu pengetahuan, penguasaan kemahiran, dan pembentukan sikap yang baik bagi siswa. Siswa dalam proses pembelajaran ini untuk mengembangkan potensinya perlu membentuk pola pikir yang baik sehingga bisa merespon dan memecahkan permasalahan yang dihadapi dalam kehidupan (Mulyono, 2017).

Hasil belajar yang optimal dapat dilihat dari ketuntasan belajarnya, terampil dalam mengerjakan tugas dan memiliki apersepsi baik terhadap pelajaran, ketika dievaluasi diharapkan hasil belajar siswa dapat meningkat. Hasil belajar siswa merupakan paradigma pembelajaran yang digunakan guru di kelas sebagai hasil interaksi tindak belajar atau hasil prestasi siswa yang telah dilakukan selama mengikuti pembelajaran. Hasil Belajar kognitif merupakan salah satu ranah hasil belajar menurut Benyamin Bloom yang merupakan hasil belajar intelektual yang terdiri dari enam aspek, yakni pengetahuan atau ingatan, pemahaman, penerapan atau aplikasi, analisis, sintesis, dan evaluasi (Sudjana, 2016).

Dari hasil observasi dan wawancara dengan salah satu guru mata pelajaran biologi di MAN 2 Ciamis untuk Kriteria Ketuntasan Minimal (KKM) mata pelajaran biologi yaitu sebesar 75, hasil belajar kognitifnya dari 170 siswa masih terdapat siswa yang belum mampu mencapai KKM dengan persentase $61 \%$ dan siswa yang nilainya sudah di atas KKM dengan persentase $39 \%$, hal ini terjadi karena dalam proses pembelajaran biologi siswa cenderung terbiasa menerima materi yang diberikan guru, kurang berpartisipasi aktif, rendahnya rasa keingintahuan siswa, sulit mengingat dan memahami materi yang dipelajari dan kurang serius dalam mengikuti pembelajaran sehingga apa yang sudah dipelajari tidak diterapkan dengan baik dan ketika dievaluasi hasil belajar nya masih kurang optimal.

Upaya untuk mengatasi kendala tersebut sebagai inovasi dalam pembelajaran dapat dilatih secara intensif dengan penggunaan model pembelajaran Discovery learning berbasis Concept mapping. Model Discovery Learning merupakan cara belajar dengan proses pembelajaran tidak diberitahukan oleh guru, tetapi siswa diharapkan berperan aktif dan menemukan sendiri informasi, memahami konsep, arti, prinsip dan hubungan yang akan di pelajarinya (Priansa, 2017).

Dari hasil penemuan siswa diterapkan dalam pembuatan Concept Mapping yang merupakan ilustrasi grafis yang menggambarkan sebuah konsep tunggal dihubungkan dengan konsep-konsep lain pada kategori yang sama (Trianto, 2011). Tujuan penelitian ini adalah untuk mengetahui pengaruh model pembelajaran Discovery Learning berbasis Concept Mapping terhadap hasil belajar kognitif siswa pada sub materi Pencemaran Lingkungan.

\section{METODE PENELITIAN}

Penelitian ini dilaksanakan pada semester genap tahun ajaran 2019/2020 pada bulan April 2020 secara daring atau online karena melihat situasi dan kondisi ditengah pandemi Covid-19 dengan siswa kelas X IPA 5 MA Negeri 2 Ciamis Jl. Yos Sudarso No.53, Kecamatan Ciamis, Kabupaten Ciamis Provinsi Jawa Barat.

Metode yang digunakan dalam penelitian ini adalah metode eksperimen semu (QuasiExperiment) yaitu Penelitian yang mendekati percobaan sungguhan saat berlangsungnya proses pembelajaran untuk mengetahui pengaruh variabel bebas untuk meningkatkan variabel terikat dimana subyek penelitian sangat dipengaruhi oleh situasi dan kondisi (Sugiyono, 2016). Dengan desain penelitian yang digunakan dalam penelitian ini One-Group Pretest-Postest.

Populasi dalam penelitian ini adalah seluruh siswa-siswi kelas X IPA MAN 2 Ciamis Tahun ajaran 2019/2020 dengan jumlah 170 siswa yang terdiri dari 5 kelas. Sampel yang digunakan satu kelas eksperimen dengan teknik Purvosive Sampling yaitu penentuan anggota sampel dari populasi dilakukan dengan pertimbangan tertentu (Sugiyono, 2016). Pertimbangannya yaitu karena nilai ratarata hasil belajar kognitif yang didapat pada kelas tersebut banyak yang kurang dari KKM dan lebih 
rendah dibandingkan kelas lainnya. Penelitian menggunakan sampel kelas X IPA 5 sebanyak 30 siswa namun pada pelaksanaan pembelajaran dari 30 siswa hanya 27 siswa yang dapat mengkuti pembelajaran secara online.

Variabel bebas dalam penelitian ini Model discovery learning berbasis concept mapping yang digunakan pada proses pembelajaran siswa, sedangkan variabel terikatnya adalah Hasil belajar kognitif, Menurut Bloom yang direvisi oleh Anderson dan Kratwohl (dalam Kuswana, 2014) hasil belajar terdiri dari 6 ranah yaitu (1) Mengingat (2) Memahami (3) Menerapkan (4) Menganalisis (5) Mengevaluasi (6) Menciptkakan.

Instrumen yang digunakan berupa tes tulis dalam bentuk soal Pilihan Ganda (PG) sebanyak 20 soal terdiri dari lima alternatif jawaban. Instrumen tes untuk mengukur hasil belajar kognitif diambil dari materi Pencemaran lingkungan dan kasus permasalahan pencemaran lingkungan yang terjadi sekarang ini. Sebelum soal-soal tersebut dijadikan sebagai bahan instrumen penelitian, terlebih dahulu dilaksanakan expert judgement oleh tiga dosen ahli (ahli konstruksi, ahli isi, dan ahli bahasa) kemudian uji coba dilakukan kepada responden, dalam hal tersebut diluar sampel yang telah ditentukan. Soal instrumen ditentukan dengan hasil analisis uji coba instrumen menggunakan uji validitas, uji reliabilitas, uji tingkat kesukaran soal dan uji daya beda soal.

Teknik analisis data menggunakan uji prasyarat dengan uji normalitas $\chi^{2}$ hitung $\leq \chi^{2}$ tabel maka data berdistribusi normal, uji hipotesis dengan uji $z Z_{\text {hitung }} \geq Z_{\text {tabel }}$ maka hipotesis diterima dan uji tingkat pengaruh dengan N-Gain. Menurut Hake (1999 dalam Simbolon, 2015) N-Gain didapat dengan cara membagi selisih skor hasil setelah diberikan perlakuan (Postest) dan sebelum diberikan perlakuan (Pretest) dengan selisih antara skor maksimal dengan skor pretest.

\section{HASIL DAN PEMBAHASAN}

Penelitian dilakukan di kelas X IPA 5 MAN 2 Ciamis semester genap tahun akademik 2019/2020 pada hari Sabtu 18 April 2020 secara daring (dalam jaringan) atau online karena situasi dan kondisi ditengah pandemi Covid-19 yang tidak memungkinkan peneliti untuk melaksanakan penelitian di kelas secara secara tatap muka maka peneliti menggunakan aplikasi Zoom dan aplikasi WhatsApp untuk kegiatan pembelajaran secara online dan Google Form untuk pengisian soal Pretes dan Postest. Penerapan model Discovery Learning berbasis Concept Mapping berpengaruh signifikan terhadap hasil belajar kognitif siswa pada submateri pencemaran lingkungan. Diperoleh data penelitian berupa pretest dan postest, data yang diperoleh yaitu berupa angka-angka. Angka tersebut merupakan gambaran tentang hasil belajar kognitif siswa yang diperoleh selama kegiatan pembelajaran.

Data hasil penelitian yang diperoleh sebagai berikut :

Tabel 1. Distribusi Nilai Hasil Belajar kognitif Siswa

\begin{tabular}{clcccc}
\hline Kelas & \multicolumn{1}{c}{ Nilai } & Pretest & Postest & Gain & N-Gain \\
\hline \multirow{3}{*}{ X IPA 5 } & Nilai Terendah Nilai & 15 & 75 & 20 & 0,7 \\
& Tertinggi & 75 & 100 & 65 & 1,0 \\
& Nilai Rata-rata & 45,56 & 88,89 & 43,33 & 0,80 \\
\hline
\end{tabular}

Data hasil penelitian berupa pretest dan postest kemudian dihitung selisihnya menjadi data Gain. Selanjutnya data Gain diuji dengan uji normalitas untuk mengetahui apakah data tersebut berdistribusi normal atau tidak Berdasarkan hasil perhitungan uji normalitas maka didapatkan data bahwa $X^{2}$ hitung $\leq X^{2}$ tabel dengan mengambil taraf signifikansi $a=1 \%$ dan data berdistribusi normal. Data hasil uji normalitas dapat dilihat pada tabel di bawah ini. 
Tabel 2. Hasil Perhitungan Uji Normalitas

\begin{tabular}{|c|c|c|c|c|c|c|c|}
\hline Data & rentang & $\begin{array}{c}\text { Banyak } \\
\text { kelas }\end{array}$ & $\begin{array}{c}\text { Panjang } \\
\text { kelas }\end{array}$ & Rata-rata & $\begin{array}{c}\text { Standar } \\
\text { deviasi }\end{array}$ & $X^{2}$ hitung & $X^{2}$ daftar \\
\hline Gain & 45 & 6 & 8 & 43,66 & 12 & 6,003 & 11,3 \\
\hline
\end{tabular}

Berdasarkan hasil uji normalitas diketahui bahwa data berdistribusi normal, selanjutnya ilakukan pengujian hipotesis menggunakan uji $Z$. Adapun untuk hasil perhitungan uji $Z$ dapat dilihat pada tabel berikut.

Tabel 3. Hasil Perhitungan Uji Hipotesis

\begin{tabular}{ccc}
\hline Zhitung & Zdaftar (1\%) & Keterangan \\
\hline 3,125 & 2,33 & Hipotesis Diterima dan \\
& & Berpengaruh Sangat \\
& & Signifikan \\
\hline
\end{tabular}

Hasil penelitian menunjukan perolehan nilai rata-rata pretest 45,56 dan rata-rata postest 88,89 . Nilai tersebut jika dibandingkan dengan nilai KKM sebesar 75 menunjukan adanya kenaikan/perubahan nilai siswa dan memenuhi kriteria minimal yang telah ditetapkan. Hasil uji NGain dengan nilai 0,80 menunjukan bahwa nilai $\mathrm{N}$-Gain termasuk kategori tinggi yang artinya terdapat terdapat peningkatan hasil belajar kognitif dengan penggunaan model discovery learning berbasis concept mapping dengan tingkat peningkatannya tinggi. Diperkuat dengan hasil Uji Normalitas diperoleh $X^{2}$ hitung $\leq X^{2}$ daftar yaitu $6,003 \leq 11,3$ ini menunjukan berdistribusi normal. Selanjutnya dilakukan uji hipotesis dengan uji $z$ diperoleh $Z_{\text {nitung }} \geq Z_{\text {daftar }}$ pada taraf signifikansi $1 \%$ yaitu $3,125 \geq 2,33$, maka dapat dikatakan bahwa hipotesis diterima. Hasil penelitian penggunaan model Discovery Learning berbasis Concept Mapping berpengaruh sangat signifikan terhadap hasil belajar kognitif siswa pada sub materi pencemaran lingkungan.

Hasil belajar merupakan hasil dari interaksi pembelajaran sebagai obyek evaluasi yang dilakukan guru kepada siswa secara menyeluruh baik dari segi pemahaman (kognitif), segi penghayatan (afektif) dan segi pengalamannya (psikomotor) (Sudijono, 2012).

Bloom (Sudjana, 2016) secara garis besar membagi hasil belajar menjadi tiga ranah, yaitu: 1) Ranah Kognitif (2) Ranah Afektif (3) Ranah Psikomotorik. Ketiga ranah tersebut menjadi obyek penilaian hasil belajar, dan yang paling banyak dinilai yaitu ranah kognitif yang berkaitan dengan kemampuan siswa menguasai isi bahan pengajaran. Hasil belajar kognitif menurut Bloom yang direvisi oleh Anderson dan Kratwohl terdiri dari enam aspek yang bersifat hierarkis meliputi: Mengingat (Remember), Memahami (Understand), Menerapkan (Apply), Menganalisis (Analyze), Mengevaluasi (Evaluate) dan Menciptakan (Create).

Hasil belajar siswa dapat meningkat didukung dengan kegiatan pembelajaran dengan penggunaan model dan metode pembelajaran yang bervariasi yang merupakan inovasi dalam memilih model dan metode yang diterapkan di kelas untuk menciptakan pembelajaran yang berpusat pada siswa, siswa berperan aktif, menarik, tidak merasa bosan, dapat menemukan pengetahuannya sendiri dan menerapkan pada kehidupan sehari-hari, sehingga pemilihan model dan metode pembelajaran yang tepat akan berpengaruh terhadap hasil belajar siswa.(Slameto, 2013)

Dalam proses pembelajaran menggunakan model discovery learning merupakan cara belajar dengan proses pembelajaran tidak diberitahukan langsung oleh guru, guru hanya memberikan stimulus, arahan dan fasilitator bagi siswa, sedangkan siswa dituntut aktif dalam menemukan sendiri permasalahan dan dituntut menemukan informasi untuk menyelesaikan permasalahan tersebut (Priansa, 2017). Dalam menemukan informasi untuk menyelesaiakan permasalahan dipadukan dengan pembuatan Concept mapping merupakan ilustrasi grafis yang menggambarkan sebuah konsep tunggal dihubungkan dengan konsep-konsep lain pada kategori yang sama (Trianto, 2011).

Concept mapping ini sebagai cara meringkas materi atau permasalahan yang telah didapatkan dalam bentuk ilustrasi grafis atau alat skematis suatu konsep yang digambarkan dalam suatu 
kerangka yang berisi informasi yang sudah dimiliki siswa dan yang sudah dipelajari yang saling terkait dengan jelas, sehingga untuk memudahkan dalam mengingat, memahami, menerapkan dengan tepat suatu materi pembelajaran yang dibahas dan dihubungkan dengan masalah yang terjadi dalam kehidupan sehari-hari, menghindari miskonsepsi oleh siswa, dan membantu dalam mempelajari konsep pokok atau topik yang sedang dipelajari dengan mengaitkan pengetahuan yang telah dimilikinya. (Isnaeni,et al,2017)

Setelah pembuatan concept mapping siswa melakukan presentasi dengan cara di video dan terjadi diskusi dan pertukaran informasi dengan siswa lainnya di grup WhatsApp sehingga diperoleh wawasan baru. Dari hasil pembelajaran tersebut ketika diberikan soal postest dengan soal yang sama dengan yang diberikan sebelumnya, maka mengalami peningkatan hasil belajar kognitifnya.

Temuan-temuan pada pelaksanaan penelitian secara daring peserta didik memiliki pendapat dan pandangan yang berbeda terhadap permasalahan yang ditemukan. Sebagian siswa masih belum terbiasa dalam pelaksanaannya masih terdapat siswa yang pasif, hal ini terjadi karena memiliki kemampuan dan latar belakang yang berbeda-beda. Namun walaupun demikian, model Discovery Learning memberikan pengaruh yang cukup besar terhadap hasil belajar kognitif, hal ini karena dengan Discovery Learning siswa dituntut untuk belajar aktif dan terlibat langsung dalam pelaksanaannya, menemukan sendiri permasalahan dan informasi untuk menyelesaikannya. Dalam pengaplikasiannya, kegiatan model Discovery learning berbasis Concept Mapping dilakukan dengan sintaks yang terdiri dari :

1. Stimulation, pada tahap ini siswa diberikan rangsangan dalam konteks masalah pencemaran lingkungan untuk melakukan eksplorasi atau penyelidikan terjadi proses berpikir analitis, siswa menghubungkan pengetahuan yang telah diperoleh sebelumnya dengan materi pencemaran lingkungan.

2. Problem Statement, pada tahap ini siswa melakukan pengamatan dan penalaran dari bahan ajar dan lembar kerja siswa terhadap masalah yang ditemukan sebagai proses berpikir sistematis dan logis.

3. Data Collection, pada tahap ini terjadi berpikir analisis dimana siswa mengumpulkan penemuanpenemuan masalah dari sumber buku dan internet yang dibuatkan dalam bentuk peta konsep sehingga mendapatkan hasil pembelajaran yang nyata dari hasil pengamatan dan uji coba.

4. Data Processing, pada tahap ini siswa mengembangkan berpikir rasional mendapatkan pengetahuan baru tentang alternatif jawaban atau penyelesaian yang perlu mendapat pembuktian secara logis.

5. Verification, pada tahap ini siswa melakukan pemeriksaan secara cermat dalam membuktikan kebenaran data yang telah didapatkan dan melakukan presentasi melakukan tanya jawab di Grup WhatsApp sehingga memperoleh informasi baru.

6. Generalization, pada tahap ini siswa mengingat, memecahkan masalah, menganalisis faktor, melihat hubungan dan membuat keputusan/kesimpulan dari pembelajaran yang telah dilakukan tentang pencemaran lingkungan.

Pelaksanaan pembelajaran dengan menggunakan model Discovery learning berbasis Concept Mapping berjalan cukup baik dan dapat memberikan pengaruh yang sangat signifikan terhadap hasil belajar kognitif pada submateri pencemaran lingkungan., akan tetapi banyak faktor yang tidak bisa diawasi oleh peneliti sehingga banyak kemungkinan yang tidak diinginkan, karena pelaksanaanya secara daring atau online melihat situasi dan kondisi ditengah pandemi Covid-19 yang tidak memungkinkan untuk melaksanakan penelitian di kelas sehingga pengawasannya kurang optimal.

Berdasarkan hasil penelitian model Discovery learning bisa dipadupadankan dengan metode Concept mapping sehingga dapat meningkatkan hasil belajar kognitif siswa, tetapi akan lebih baik kalau pelaksanaanya secara langsung tatap muka di kelas. Peneliti menyadari adanya kelemahan dalam penelitian ini karena tidak menutup kemungkinan siswa ada yang membuka buku, 
membuka google atau meminta bantuan orang lain dalam mengerjakan soalnya. Selain itu dalam pelaksanaannya banyak mengalami kendala dengan jaringan/sinyal internet sehingga menghambat proses pembelajaran dan kurang optimal. Solusi yang dilakukan peneliti terhadap permasalahan tersebut dengan cara mengawasi di grup WhatsApp atau menghubungi lewat pesan pribadi pada siswa yang tidak muncul di grup dan dipersilahkan untuk mencari koneksi internet yang baik serta memberikan keringanan untuk mengirimkan jawaban menyusul dengan jangka waktu tertentu bagi siswa yang benar-benar terkendala jaringan internet.

\section{KESIMPULAN}

Penggunaan model Discovery Learning berbasis Concept Mapping berpengaruh sangat signifikan terhadap hasil belajar kognitif pada sub materi pencemaran lingkungan. Model pembelajaran yang digunakan dapat meningkatkan hasil belajar kognitif yang diperoleh setelah dilaksanakannya kegiatan pembelajaran dengan tingkat peningkatan yang tinggi yaitu sebesar 0,80.

\section{REKOMENDASI}

Sebaiknya guru atau peneliti lebih inovatif dalam melakukan pembelajaran yang dapat mendukung terhadap tercapainya tujuan pembelajaran.

\section{UCAPAN TERIMA KASIH}

Penulis mengucapkan terima kasih kepada siswa kelas X IPA 5 MAN 2 Ciamis yang telah mendukung terhadap penelitian ini.

\section{DAFTAR PUSTAKA}

Isnaini, M. Syarifah, dan Afriansyah, (2017). "Pengaruh Metode Peta Konsep (Menggunakan Macromedia Flash) Untuk Meningkatkan Hasil Belajar Kognitif Siswa". Jurnal Didaktika Biologi 1(1): 55-60.

Kuswana, W. (2014). Taksonomi Kognitif Perkembangan Ragam Berpikir. Bandung. PT Remaja

Rosdakarya.

Mulyono, N. (2017). Kurikulum dan Pembelajaran. Bandung. Rizki Press.

Priansa, D.J. (2017). Pengembangan Strategi dan Model Pembelajaran. Bandung. CV Pustaka Setia.

Simbolon, E.R dan Tapilouw F.S (2015). "Pengaruh Pembelajaran Berbasis Masalah dan

Pembelajaran Kontekstual Terhadap Berpikir Kritis Siswa SMP”. Edusains. 7(1):97-104.

Slameto. (2013). Belajar dan Faktor-Faktor Yang Mempengaruhi. Jakarta. Rineka Cipta

Sudijono, A. (2012). Pengantar Evaluasi Pendidikan. Depok. PT Rajagrafindo Persada.

Sudjana, N. (2016). Penilaian Hasil Proses Belajar Mengajar.Bandung. PT Remaja Rosdakarya Sugiyono. (2016). Metode Penelitian Kuantitatif, Kualitatif dan R\&D. Bandung. Alfabeta.

Trianto. (2011). Mendesain Model Pembelajaran Inovatif-Progresif. Jakarta. Kencana Prenada Media Group. 